\title{
DISTRIBUTION AND ABUNDANCE OF PLEURONECTIFORMES LARVAE OFF SOUTHEASTERN BRAZIL
}

\author{
Camilla Nunes Garbini*, Maria de Lourdes Zani-Teixeira, \\ Márcio Hidekazu Ohkawara and Mario Katsuragawa \\ Instituto Oceanográfico da Universidade de São Paulo \\ (Praça do Oceanográfico, 191, 05508-120 São Paulo, SP, Brasil) \\ *Corresponding author: camillanunes1@gmail.com
}

http://dx.doi.org/10.1590/S1679-87592014051706201

ABSTRACT

The objective of this study was the description of the composition, abundance and density in horizontal and vertical distribution of Pleuronectiformes larvae on the southeastern Brazilian continental shelf. The samples were collected with bongo nets and a Multi Plankton Sampler (MPS), both in summer and winter 2002. A total of 352 flatfishes larvae were collected in summer and 343 in winter, representing three families and a total of 13 taxa: Paralichthyidae (Citharichthys cornutus, $C$. spilopterus, Citharichthys sp., Cyclopsetta chittendeni, Syacium spp., Etropus spp. and Paralichthys spp.), Bothidae (Bothus ocellatus and Monolene antillarum) and Cynoglossidae (Symphurus trewavasae, S. jenynsi, S. plagusia and S. ginsburgi). The most abundant taxa were Etropus spp., Syacium spp. and Bothus ocellatus. Etropus spp. occurred mainly as far out as the $200 \mathrm{~m}$ isobath and Syacium spp. from $100 \mathrm{~m}$. B. ocellatus was present mainly in the oceanic zone between Ubatuba and Rio de Janeiro as from the $200 \mathrm{~m}$ isobath. The greatest average densities of these species occurred in the strata from 0 to $20 \mathrm{~m}$ depth in summer and between 20 and $40 \mathrm{~m}$ in winter.

\section{RESUMO}

O objetivo deste estudo foi descrever a composição, abundância, densidade, distribuição horizontal e vertical das larvas de Pleuronectiformes ao longo da plataforma continental Sudeste brasileira. As amostras foram coletadas na plataforma continental sudeste com redes bongô e Multi Plankton Sampler (MPS), no verão e inverno de 2002. Um total de 352 larvas de linguado foi coletado no verão e 343 no inverno, representadas por três famílias e totalizando 13 táxons: Paralichthyidae (Citharichthys cornutus, C. spilopterus, Citharichthys sp., Cyclopsetta chittendeni, Syacium spp., Etropus spp. e Paralichthys spp.), Bothidae (Bothus ocellatus e Monolene antillarum) e Cynoglossidae (Symphurus trewavasae, S. jenynsi, S. plagusia e S. ginsburgi). Os táxons mais abundantes foram Etropus spp., Syacium spp. e Bothus ocellatus. Etropus spp. ocorreram principalmente até a isóbata de $200 \mathrm{~m}$ e Syacium spp. a partir de $100 \mathrm{~m}$. B. ocellatus esteve presente principalmente na zona oceânica entre Ubatuba e Rio de Janeiro a parir da isóbata de $200 \mathrm{~m}$. As maiores densidades médias dessas espécies ocorreram nos estratos de 0 a $20 \mathrm{~m}$ de profundidade, no verão, e entre 20 a 40 m, no inverno.

Descriptors: Fish larvae, Temporal variation, Horizontal distribution, Vertical distribution, Flatfishes. Descritores: Larvas de peixes, Variação temporal, Distribuição horizontal, Distribuição vertical, Linguados.

\section{INTRODUCTION}

Much of our knowledge of fish ecology comes from studies on species of commercial interest or which are otherwise abundant in coastal waters; however, few studies focus on the initial stages of the life-cycle of the Pleuronectiformes. The larger part of the available information relates to the species of the Northern Hemisphere, particularly to the adult phase of those which are commercially important (MARQUES et al., 2009; MUNROE; ROSS, 2010).
Recent studies have concentrated particularly on the cultivation of Paralichthys olivaceus in China and Japan (OHNO et al., 2008; SHIROZU et al., 2008; YAMAGUCHI; KITANO, 2008; CHEN et al., 2009; HUANG et al., 2010; SUN et al., 2010).

In Brazil, studies on flatfish, based on adults, deal with various aspects: morphology (MENEZES; BENVEGNÚ, 1976); occurrence, distribution and abundance (LEMA; OLIVEIRA, 1977; LEMA et al., 1980; PAIVA-FILHO et al., 1989; ALMEIDA; VASCONCELOS FILHO, 1997; MENDONÇA; 
ARAÚJO, 2002), reproductive dynamics (CHAVES; VENDEL, 1997; PAIVA et al., 2001; MENDONÇA; ARAÚJO, 2002; DIAS et al., 2005); feeding (WAKABARA et al., 1982; CHAVES; SERENATO, 1998; LUNARDON-BRANCO; BRANCO, 2003; GUEDES et al., 2004); occurrence of parasites (ROBALDO et al., 2002; THATCHER; PEREIRA Jr., 2004; ABREU et al., 2005; CARDENAS; LANFREDI, 2005; VELLOSO et al., 2005), and genetic characterization (AZEVEDO et al., 2005, 2007).

Recent work on the larvae of the Pleuronectiformes has dealt mainly with $P$. olivaceus and has been undertaken in China and Japan (TANAKA et al., 2005; SAKAKURA, 2006; ISHIBASHI et al., 2007; SHIMADA; SEIKAI, 2008a, 2008b; TOMIYAMA et al., 2008). In Brazil studies have focused more on transport (ARAÚJO-LIMA; OLIVEIRA, 1998), reproductive aspects (SAMPAIO et al., 2007) and aquiculture (LANES et al., 2008). Kurtz and Matsuura (1994) conducted an in-depth study on the Cynoglossidae. On the other hand, in other studies, such as those of Castro et al. (2005), Katsuragawa and Dias (1997), flatfish larvae have been analyzed more superficially, as they focused on the total ichthyoplankton population. This brings out the need for more detailed studies on this group with a view to increasing knowledge of the initial phases of their life-cycle, as also to contributing to our understanding of the flatfish ecology and population dynamics on the southeastern coast of Brazil. This study aims to describe the composition, abundance and density in horizontal and vertical distribution of flatfishes larvae in southeastern Brazilian waters.

\section{Material and Methods}

The samples analyzed were collected on two oceanographic cruises undertaken in 2002, establishing a total, in summer, of 72 stations distributed on 14 transects and, in winter, of 66 stations on 13 transects. The study area extended from the coast as far out as the oceanic region, being limited to the north by the São Tomé Cape and to the south by São Sebastião Island (Fig. 1). This area was subdivided into three regions in accordance with their respective depths: coastal zone (out to the $100 \mathrm{~m}$ isobath), intermediate zone (between the 100 and 200 $\mathrm{m}$ isobaths) and the oceanic zone (beyond the $200 \mathrm{~m}$ isobath).

Hydrographic data were obtained with the help of a CTD (Conductivity, Temperature, and Depth Sensor). T-S diagrams were traced for the purpose of identifying the water masses by means of the thermohaline indices described by Sverdrup et al. (1942), Emílsson (1961) and Miranda (1985). The $10 \mathrm{~m}$ depth temperature was used to try to explain the horizontal distribution of larvae. This depth was in the range $(0-20 \mathrm{~m})$ where the greatest abundance of ichthyoplankton is observed.

The samples were obtained on oblique trawls with a bongo net with a $60 \mathrm{~cm}$ diameter mouth and an MPS (Multi Plankton Sampler) with $1 \mathrm{~m}^{2}$ mouth area, both with $333 \mu \mathrm{m}$ mesh size. Whenever, possible the bongo net gathered samples from the surface down to 200 m depth (SMITH; RICHARDSON, 1977). The MPS composed of five nets with an opening and closing system, operated on strata of $20 \mathrm{~m}$ down to $100 \mathrm{~m}$ depth, on alternate transects. Mechanical flowmeters were coupled to all the nets to estimate the volume of water filtered (SMITH; RICHARDSON, 1977).

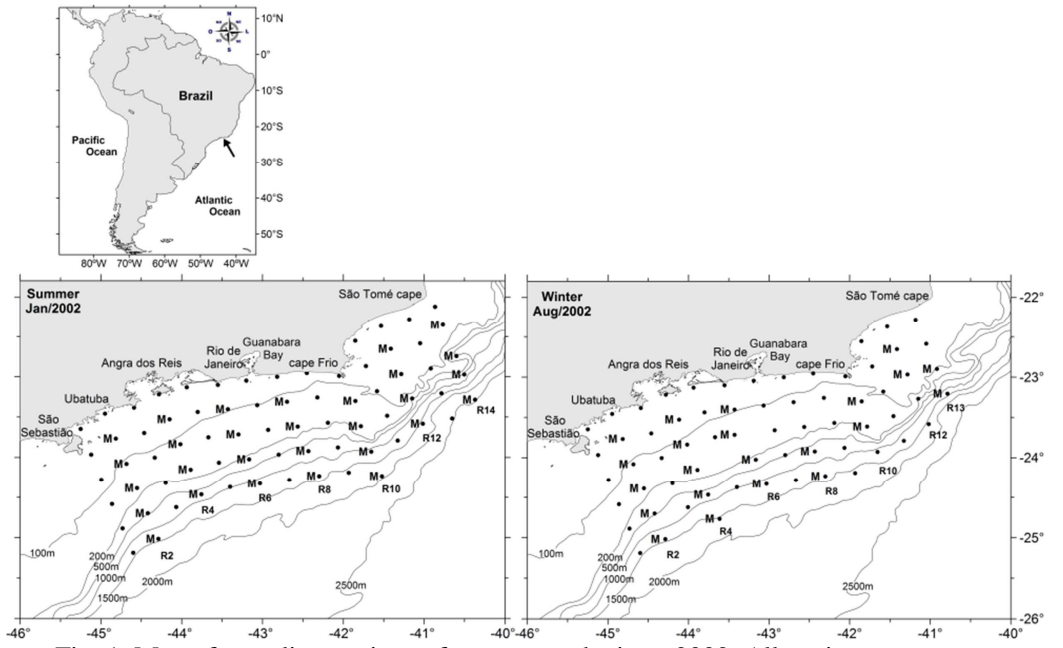

Fig. 1. Map of sampling stations of summer and winter 2002. All stations were sampled with bongo net and, the marked one with M, with MPS in alternating radial (R) 
The identification of some species was carried out by development series such as AcevesMedina et al. (1999) and Saldierna-Martinez et al. (2010). Larvae of the genera Etropus and Syacium underwent the process of clearing and staining techniques (POTTHOFF, 1984) to show meristic characteristics that would make the identification to species level possible.

The estimate of larval abundance at each station was arrived at by means of the expression $Y=\frac{d \times x}{v}$, where $\boldsymbol{Y}$ is the number of larvae per $\mathrm{m}^{2}, \boldsymbol{d}$ the depth at which the collection was made (m), $\boldsymbol{x}$ the number of individuals collected at the station, and $v$ the volume of water filtered $\left(\mathrm{m}^{3}\right)$. From the samples obtained with the MPS net, the density of the larvae at each station and on each stratum was estimated by means of the expression $N=\frac{x}{v}$, where $N$ is the number of larvae per $\mathrm{m}^{3}, \boldsymbol{x}$ the number of individuals from one of the strata at the collection station, and $v$ the volume of water filtered $\left(\mathrm{m}^{3}\right)$ on that same stratum.

Mann-Whitney's non-parametric analytical test (ZAR, 1999) was used to ascertain significant differences between biological data such as larval density and abundance and relation to collection period (summer and winter).

\section{RESULTS}

\section{Oceanographic Conditions}

The Brazil Current transports two water masses southward: Tropical Water (TW) near the shelf break in the upper layer of $200 \mathrm{~m}$ depth with temperature and salinity higher than $20^{\circ} \mathrm{C}$ and 36.40 respectively (CASTRO; MIRANDA, 1998); South Atlantic Central Water (SACW) at 200-500m depth with salinity and temperature lower than those of TW. Another water mass, Coastal Water $(\mathrm{CW})$, is derived from mixing of shelf and continental origin waters resulting in low salinity water (SILVEIRA et al., 2000).

It may be observed, on the basis of the scattered T-S diagram, in both the periods studied TW, that SACW and CW occurred in the water column sampled. The periods presented variations by virtue of the mixing of the water masses in the upper part of the water column. In summer the TW predominated on the shelf, while in winter a larger contribution of the $\mathrm{CW}$ was observed (Fig. 2). Upwelling was present in summer, when SACW was observed on the shelf, whereas in winter this water mass was evident as from the intermediate zone, corresponding to the middle shelf.

At $10 \mathrm{~m}$ depth, the highest temperatures were recorded in the south of the study area and also beyond the $200 \mathrm{~m}$ isobath (Fig. 3). Colder waters were observed in the coastal zone between Cape Frio and Guanabara Bay and in the region of Cape São Tomé. In winter the range of temperature variation was smaller (Fig. 3). An upwelling promoted by the intrusion of SACW, could be observed in the Cape Frio region and with greater intensity in summer. When the summer salinity results were analyzed the water column was seen to be homogeneous throughout. In winter, however, the salinity varied more than in summer (Table 1). The lowest average values were found at $10 \mathrm{~m}$, in the coastal zone near São Sebastião and Angra dos Reis. Values above 37 were only observed beyond the $500 \mathrm{~m}$ isobath, between the depths of 10 and $50 \mathrm{~m}$.
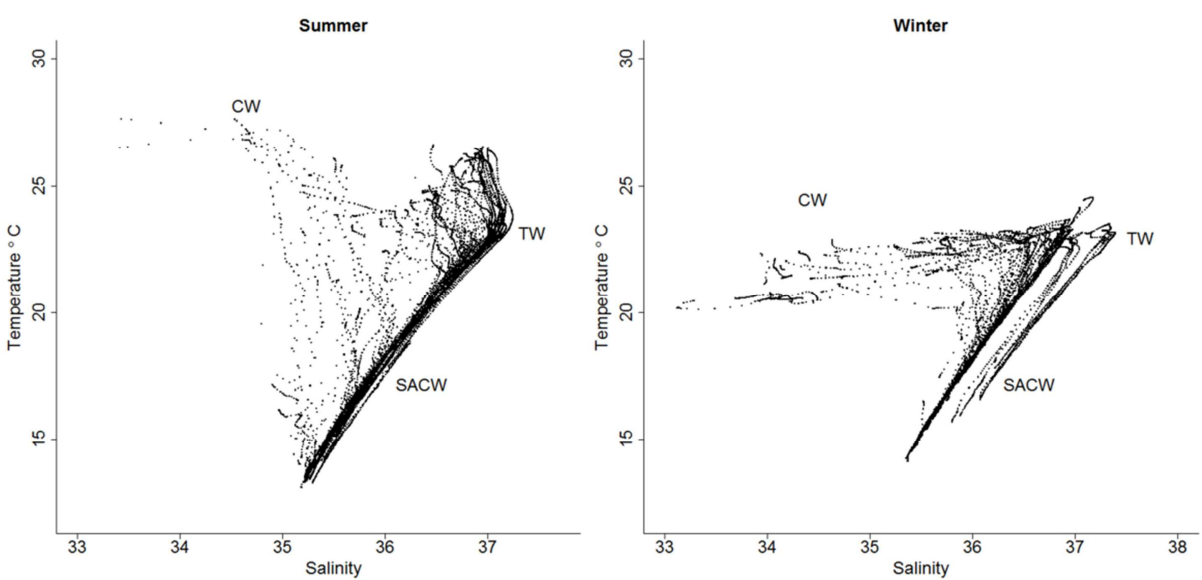

Fig. 2. T-S diagrams of the total oceanographic stations realized during the summer and winter cruises. (TW Tropical Water mass; SACW - South Atlantic Central Water mass; CW - Coastal Water mass). 


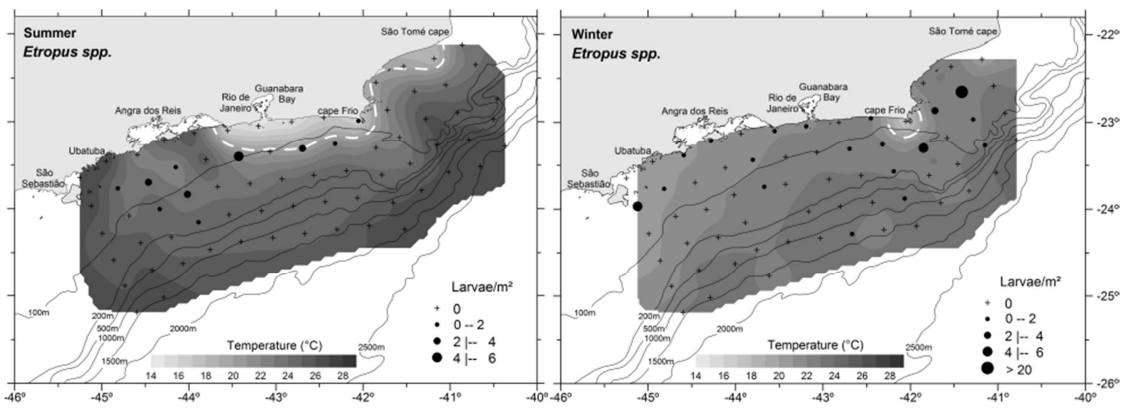

Fig. 3. Horizontal distribution of Etropus spp. during the summer and winter 2002. The abundance is expressed in larvae $/ \mathrm{m}^{2}$. Horizontal section of temperature at $10 \mathrm{~m}$ depth. The dotted white line represents the characteristic temperature $\left(20^{\circ} \mathrm{C}\right)$ of SACW (South Atlantic Central Water mass).

Table 1 . Temperature $\left({ }^{\circ} \mathrm{C}\right)$ and salinity registered by depth during the summer and winter 2002 (sd - standard deviation).

\begin{tabular}{|c|c|c|c|c|c|c|c|c|c|}
\hline & \multirow[b]{2}{*}{ depth } & \multicolumn{4}{|c|}{ Temperature $\left({ }^{\circ} \mathrm{C}\right)$} & \multicolumn{4}{|c|}{ Salinity } \\
\hline & & mean & sd & maximum & minimum & mean & sd & maximum & minimum \\
\hline \multirow{5}{*}{ summer } & $10 \mathrm{~m}$ & 23.79 & 2.86 & 27.08 & 14.88 & 36.08 & 0.69 & 37.01 & 34.67 \\
\hline & $30 \mathrm{~m}$ & 21.84 & 3.64 & 26.36 & 14.27 & 36.38 & 0.57 & 37.18 & 35.19 \\
\hline & $50 \mathrm{~m}$ & 20.97 & 3.61 & 25.91 & 13.74 & 36.46 & 0.61 & 37.12 & 35.24 \\
\hline & $100 \mathrm{~m}$ & 19.00 & 3.19 & 23.35 & 13.55 & 36.23 & 0.64 & 37.18 & 35.25 \\
\hline & $150 \mathrm{~m}$ & 17.77 & 2.80 & 22.33 & 13.35 & 35.99 & 0.53 & 36.95 & 35.23 \\
\hline \multirow[t]{5}{*}{ winter } & $10 \mathrm{~m}$ & 22.38 & 1.20 & 24.44 & 16.50 & 35.55 & 0.95 & 37.09 & 33.79 \\
\hline & $30 \mathrm{~m}$ & 22.34 & 1.50 & 24.45 & 14.64 & 36.17 & 0.78 & 37.09 & 34.18 \\
\hline & $50 \mathrm{~m}$ & 21.56 & 1.78 & 24.41 & 17.61 & 36.47 & 0.50 & 37.17 & 34.35 \\
\hline & $100 \mathrm{~m}$ & 18.85 & 2.40 & 22.69 & 14.83 & 36.14 & 0.42 & 36.85 & 35.45 \\
\hline & $150 \mathrm{~m}$ & 17.29 & 1.58 & 19.35 & 14.60 & 35.85 & 0.27 & 36.21 & 35.42 \\
\hline
\end{tabular}

\section{Horizontal Distribution}

A total of 579 flatfishes larvae were collected, 282 of them in summer $(2.34 \pm 2.68$ larvae $\left./ \mathrm{m}^{2}\right)$ and 297 in winter $\left(1.64 \pm 3.49\right.$ larvae $\left./ \mathrm{m}^{2}\right)$. In both periods the families Paralichthyidae (Citharichthys cornutus, C. spilopterus, Citharichthys sp., Cyclopsetta chittendeni, Syacium spp., Etropus spp. and Paralichthys spp.), the most abundant (36\% of the total of the order in summer and $51 \%$ in winter),
Bothidae (Bothus ocellatus and Monolene antillarum) and Cynoglossidae (Symphurus trewavasae, S. jenynsi, $S$. plagusia and $S$. ginsburgi) were identified (Table 2). The most abundant taxa, Etropus spp., Syacium spp. and Bothus ocellatus, accounted, in summer, for $36 \%$ of the total flatfishes larvae captured and, in winter, for $50 \%$. Syacium spp. (U-test, $\mathrm{p}=0.0117$ ) and $B$. ocellatus (U-test, $\mathrm{p}=0.0352$ ) were more abundant in summer.

Table 2. Data participation (N \%) of each species in the total number of larvae collected from each family, mean abundance (larvae/ $\mathrm{m}^{2}$ ) with standard deviation and frequency of occurrence (F.O. \%) during the summer and winter 2002.

\begin{tabular}{|c|c|c|c|c|c|c|c|}
\hline Family & Genus/Species & $\begin{array}{c}\mathrm{N} \\
(\%)\end{array}$ & $\begin{array}{c}\text { Summer } \\
\text { Abundance } \\
\left(\text { larvae } / \mathrm{m}^{2}\right)\end{array}$ & $\begin{array}{l}\text { F.O. } \\
(\%)\end{array}$ & $\begin{array}{c}\mathrm{N} \\
(\%)\end{array}$ & $\begin{array}{c}\text { Winter } \\
\text { Abundance } \\
\left(\text { larvae } / \mathrm{m}^{2}\right)\end{array}$ & $\begin{array}{l}\text { F.O. } \\
(\%)\end{array}$ \\
\hline \multirow{8}{*}{ Paralichthyidae } & Etropus spp. & 32.7 & $0.29 \pm 0.89$ & 13.9 & 88.0 & $0.66 \pm 2.73$ & 30.3 \\
\hline & Syacium spp. & 38.6 & $0.33 \pm 0.57$ & 31.9 & 8.0 & $0.07 \pm 0.27$ & 7.6 \\
\hline & Citharichthys cornutus & 7.9 & $0.07 \pm 0.27$ & 8.3 & - & - & - \\
\hline & Citharichthys spilopterus & 4.0 & $0.04 \pm 0.25$ & 2.8 & - & - & - \\
\hline & Citharichthys sp. & 2.0 & $0.01 \pm 0.09$ & 2.8 & - & - & - \\
\hline & Cyclopsetta chittendeni & - & $0.01-0.00$ & $\begin{array}{c}2.0 \\
-\end{array}$ & 0.7 & $0.003 \pm 0.03$ & 1.5 \\
\hline & Paralichthys spp. & 3.0 & $0.03 \pm 0.22$ & 2.8 & 3.3 & $0.04 \pm 0.22$ & 4.5 \\
\hline & Paralichthyidae N.I. & 11.9 & $0.06 \pm 0.26$ & 6.9 & - & - & - \\
\hline \multirow[t]{3}{*}{ Bothidae } & Bothus ocellatus & 37.5 & $0.32 \pm 0.76$ & 25.0 & 57.14 & $0.04 \pm 0.21$ & 4.5 \\
\hline & Monolene antillarum & 31.3 & $0.21 \pm 1.11$ & 9.7 & 14.29 & $0.01 \pm 0.10$ & 1.5 \\
\hline & Bothidae N.I. & 31.3 & $0.25 \pm 0.90$ & 13.9 & 28.57 & $0.01 \pm 0.04$ & 3.0 \\
\hline \multirow[t]{5}{*}{ Cynoglossidae } & Symphurus trewavasae & 25.0 & $0.02 \pm 0.13$ & 4.2 & 22.7 & $0.03 \pm 0.16$ & 4.5 \\
\hline & Symphurus jenynsi & 16.7 & $0.02 \pm 0.11$ & 2.8 & - & - & - \\
\hline & Symphurus plagusia & 8.3 & $0.003 \pm 0.03$ & 1.4 & - & - & - \\
\hline & Symphurus ginsburgi & - & - & - & 72.7 & $0.15 \pm 0.73$ & 7.6 \\
\hline & Cynoglossidae N.I. & 50.0 & $0.03 \pm 0.12$ & 6.9 & 4.5 & $0.005 \pm 0.04$ & 1.5 \\
\hline
\end{tabular}


Etropus spp. was the second most abundant taxon in summer, accounting for $33 \%$ of the total of Paralichthyidae larvae captured and occurring at 14\% of the stations sampled; in winter it was the most abundant of the family accounting for $88 \%$ of the larvae collected at $30 \%$ of the stations sampled. Its occurrence in summer was limited to the $200 \mathrm{~m}$ isobath, having its greatest frequency and abundance (F.O. $=25 \% ; 0.53 \pm 1.14 \quad$ larvae $\left./ \mathrm{m}^{2}\right)$ in the intermediate zone. In winter it was more widespread and occurred from the coast as far out as near to the $1500 \mathrm{~m}$ isobath, though more frequent and abundant in the coastal zone (F.O. $=44 \% ; 1.21 \pm 4.12$ larvae $/ \mathrm{m}^{2}$ ), specially in the Cape Frio region. There was no statistically significant difference in abundance as between the periods (U-test, $\mathrm{p}=0.0767$ ) (Fig. 3).

Syacium spp. In summer, the larvae of Syacium spp. were the most abundant $(0.33 \pm 0.57$ larvae $\left./ \mathrm{m}^{2}\right)$, both as regards the Paralichthyidae larvae and among the Pleuronectiformes. The greatest abundances were found in the intermediate zone $(0.61$ \pm 0.70 larvae $\left./ \mathrm{m}^{2}\right)$. In winter, in lesser abundance $(0.07$ \pm 0.27 larvae $\left./ \mathrm{m}^{2}\right)$, they only occurred at five stations (F.O. $=8 \%$ ) (Fig. 4).

Bothus ocellatus. During the summer, with abundance of $0.32 \pm 0.76$ larvae $/ \mathrm{m}^{2}$ and frequency of occurrence of $25 \%$, this species occurred mainly in the oceanic area between the 500 and 1500 m isobaths; in winter it presented low abundance $(0.04 \pm 0.21$ larvae $/ \mathrm{m}^{2}$ ) and occurrence (4 larvae at 3 stations) (Fig. $5)$.

Other species. The larvae of Paralichthys spp., Monolene antillarum and Symphurus trewavasae occurred in both periods, the first two in the intermediate zone and $S$. trewavasae mainly in the coastal zone. The species of the genus Citharichthys (Citharichthys sp., C. spilopterus and C. cornutus) and Symphurus jenynsi only occurred in summer in the coastal zone between the region of Angra dos Reis and Cape São Tomé. Symphurus ginsburgi only occurred in winter, in the intermediate zone off Angra dos Reis and Cape Frio.

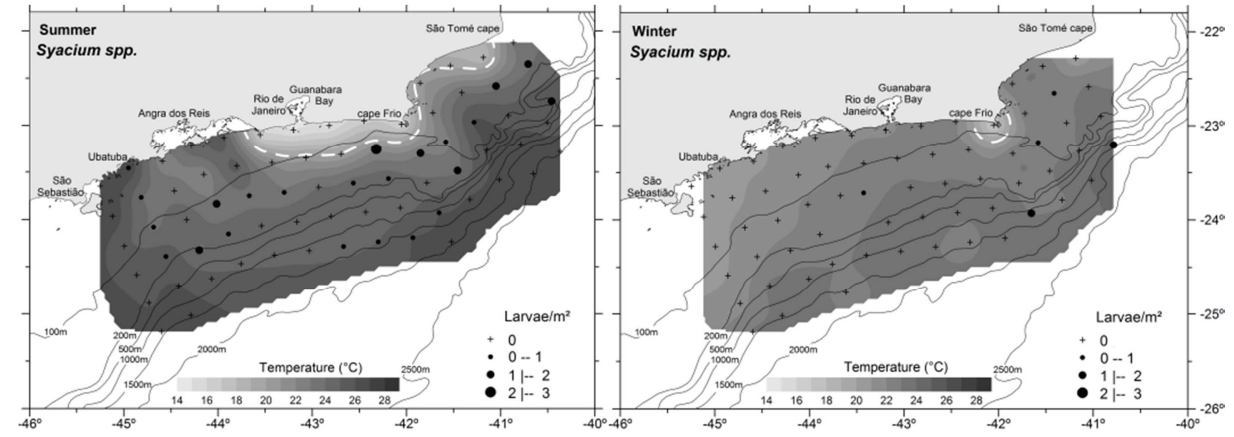

Fig. 4. Horizontal distribution of Syacium spp. during the summer and winter 2002. The abundance of larvae is expressed in larvae $/ \mathrm{m}^{2}$. Horizontal section of temperature at $10 \mathrm{~m}$ depth. The dotted white line represents the characteristic temperature $\left(20^{\circ} \mathrm{C}\right)$ of SACW (South Atlantic Central Water mass).

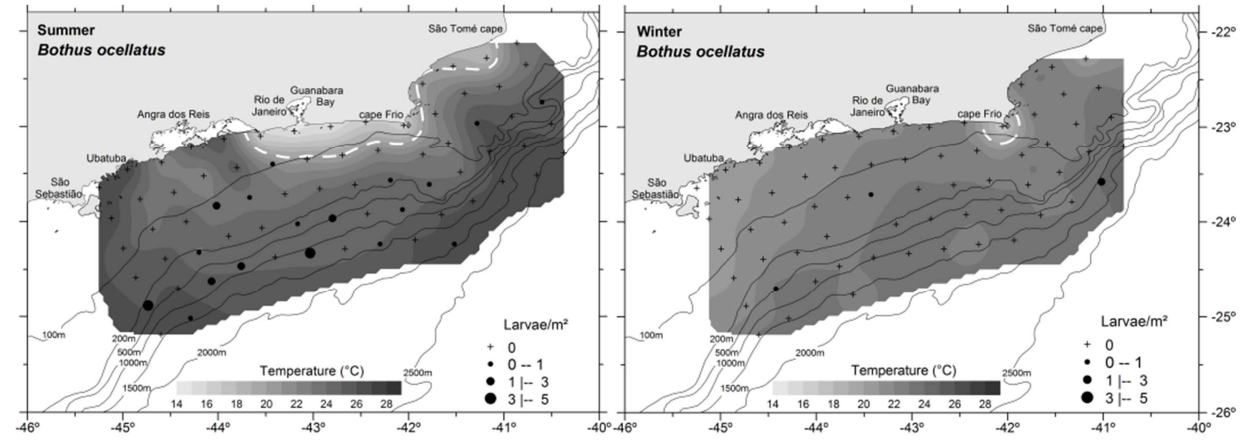

Fig. 5. Horizontal distribution of Bothus ocellatus during the summer and winter 2002. The abundance of larvae is expressed in larvae $/ \mathrm{m}^{2}$. Horizontal section of temperature at $10 \mathrm{~m}$ depth. The dotted white line represents the characteristic temperature $\left(20^{\circ} \mathrm{C}\right)$ of SACW (South Atlantic Central Water mass). 
There was just one occurrence each of Cyclopsetta chittendeni and Symphurus plagusia - that of the former species was recorded in the region of Ubatuba, in winter, and that of the latter, in summer, to the north of Cape Frio, both near the coast.

\section{Vertical Distribution}

A total of 116 flatfishes larvae were collected with MPS, 70 in summer, with an average density of $2.24 \pm 5.61$ larvae $/ 100 \mathrm{~m}^{3}$, and 46 in winter with $1.28 \pm 5.35$ larvae $/ 100 \mathrm{~m}^{3}$. With this net, of the taxa collected with the bongo net, no specimens of Citharichthys sp., C. spilopterus, Cyclopsetta chittendeni, or Paralichthys spp. were found.

Etropus spp. In summer the larvae of Etropus spp. occurred mainly in the surface stratum $\left(1.45 \pm 4.75\right.$ larvae $\left./ 100 \mathrm{~m}^{3}\right)$, whereas in winter they were more widely scattered, occupying the first three strata, although with their greatest density in the 20-40 $\mathrm{m}$ layer $\left(2.56 \pm 8.36\right.$ larvae/100 $\left.\mathrm{m}^{3}\right)$. The larvae of Etropus spp. occurred mainly in association with TW, with temperatures varying between $14.9^{\circ}$ and $26.5^{\circ} \mathrm{C}$ and average salinity of $35.7 \pm 0.3$ (Fig. 6).

Syacium spp. The larvae of this group were more abundant in summer. In terms of vertical distribution they were collected in the first two strata, the greatest abundance being observed between 0 and $20 \mathrm{~m}$, both in summer $\left(1.13 \pm 2.86\right.$ larvae $\left./ 100 \mathrm{~m}^{3}\right)$ and in winter $\left(0.41 \pm 1.08\right.$ larvae $\left./ 100 \mathrm{~m}^{3}\right)$. In summer they occurred in the deepest stratum at just one station. The variation of temperature and salinity in which the larvae were sampled was between $16.1^{\circ}$ and $25.8^{\circ} \mathrm{C}$ and 35.2 and 37.1. Their occurrence was limited to TW and the mixing zone between TW and SACW (Fig. 7).
SUMMER - Etropus spp.
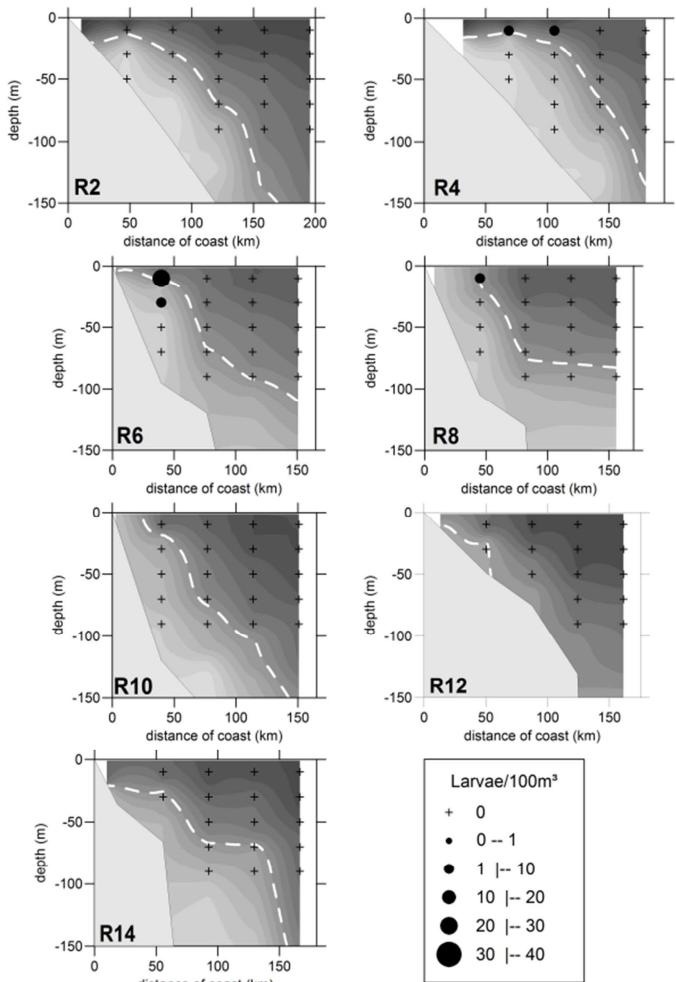

ㄸำ Temperature $\left({ }^{\circ} \mathrm{C}\right)$
WINTER - Etropus spp.
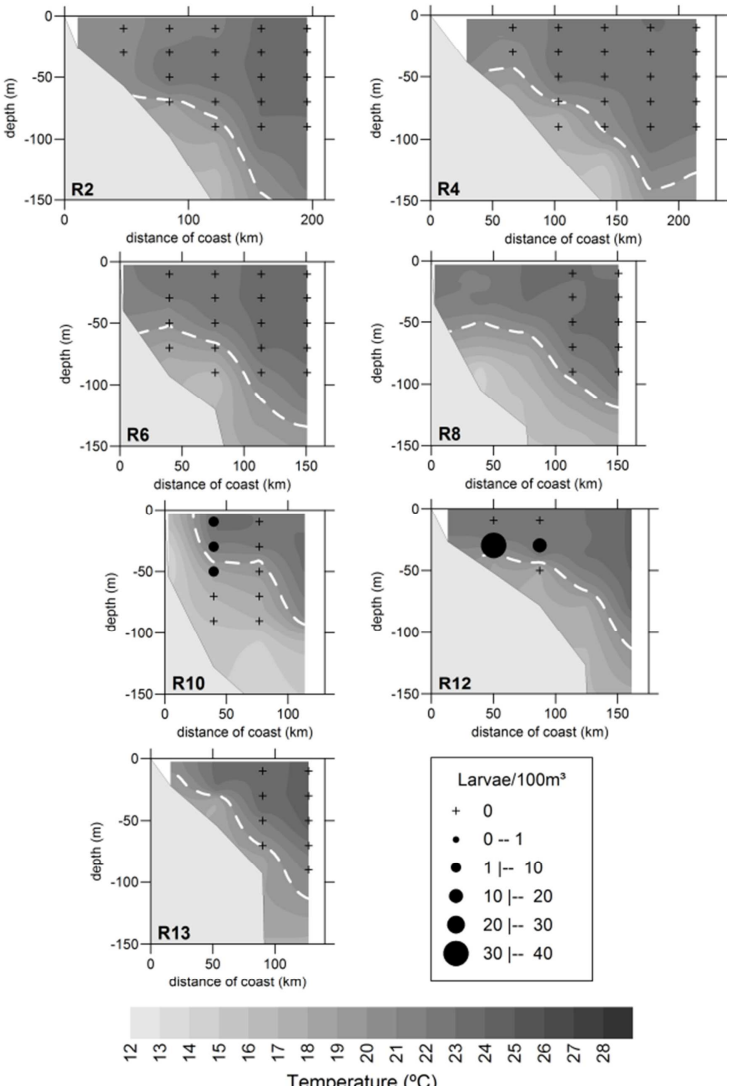

Temperature $\left({ }^{\circ} \mathrm{C}\right)$

Fig. 6. Vertical profiles of temperature $\left({ }^{\circ} \mathrm{C}\right)$ and vertical distribution of Etropus spp. larvae during the summer and winter 2002. The density is expressed in larvae $/ 100 \mathrm{~m}^{3}$. The dotted white line represents the characteristic temperature $\left(20^{\circ} \mathrm{C}\right)$ of SACW (South Atlantic Central Water mass). 
SUMMER - Syacium spp.
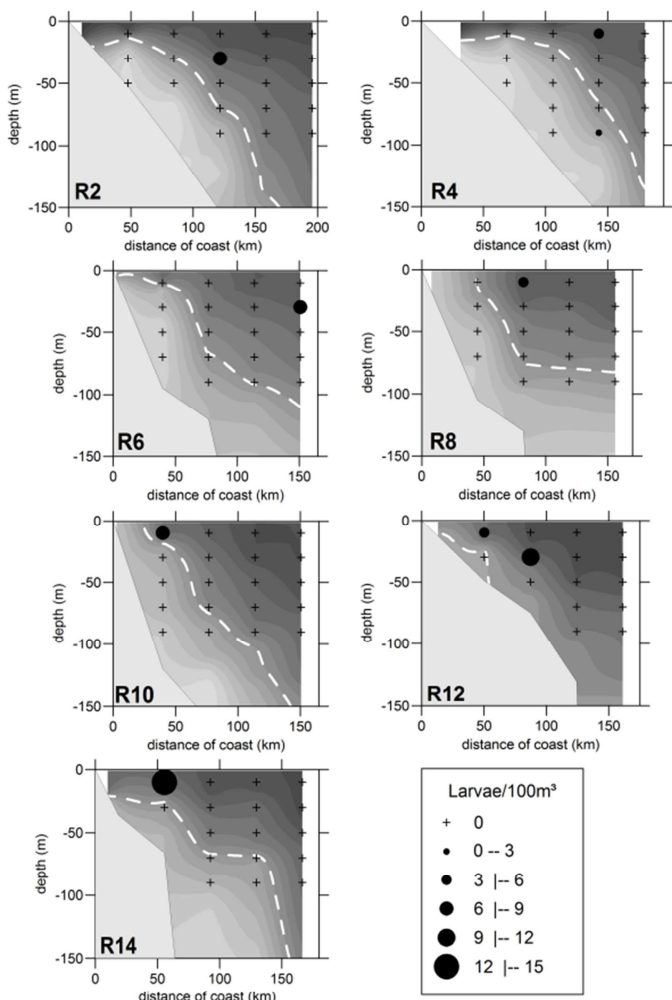

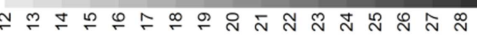
Temperature $\left({ }^{\circ} \mathrm{C}\right)$
WINTER - Syacium spp.
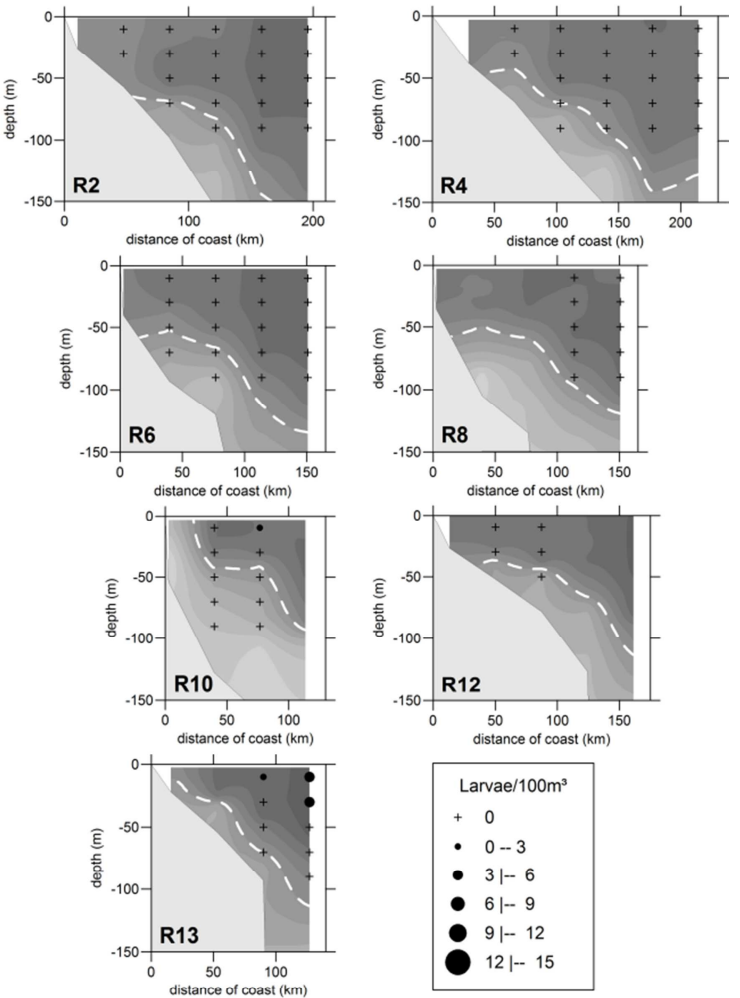

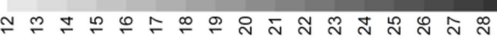

Temperature $\left({ }^{\circ} \mathrm{C}\right)$

Fig. 7. Vertical profiles of temperature $\left({ }^{\circ} \mathrm{C}\right)$ and vertical distribution of Syacium spp. larvae during the summer and winter 2002. The density is expressed in larvae $/ 100 \mathrm{~m}^{3}$. The dotted white line represents the characteristic temperature $\left(20^{\circ} \mathrm{C}\right)$ of $\mathrm{SACW}$ (South Atlantic Central Water mass).

Bothus ocellatus. Larvae of Bothus ocellatus only occurred in summer and in the first three strata, with their greatest average density $(1.61 \pm 3.85$ larvae $/ 100 \mathrm{~m}^{3}$ ) in the surface layer. They were found in regions with temperatures varying between $21.8^{\circ}$ and $25.8^{\circ} \mathrm{C}$, and salinity of between 35.2 and 36.9. Their occurrence was limited to TW and the mixing zone between TW and SACW (Fig. 8).

Other species. Only one larva of each of the following species was sampled: Cyclopsetta chittendeni, Monolene antillarum, Symphurus trewavasae, S. plagusia and S. jenynsi. Both $C$. chittendeni and $M$. antillarum were sampled in summer, the former in the 40-60 m layer, and the latter in the surface stratum. The larvae of the genus Symphurus only occurred in winter, S. trewavasae and $S$. plagusia only in the surface stratum and $S$. jenynsi only in the $20-40 \mathrm{~m}$ stratum.
Only one larva of Citharichthys cornutus was captured in summer, in the $20-40 \mathrm{~m}$ stratum, and one in winter, in the surface stratum.

Symphurus ginsburgi occurred in winter at two stations, one in the first stratum and the other in the second, to a total of six individuals.

\section{DisCUSSION}

A spatial segregation between Etropus species has been observed on the south-southeastern coast of Brazil in several studies. E. crossotus lives in shallow waters, especially in bays and estuaries, while E. longimanus inhabits coastal areas up to $190 \mathrm{~m}$ depth, being more frequent from $40 \mathrm{~m}$ (PAIVAFILHO et al., 1987; GIANNINI; PAIVA FILHO, 1995; ROCHA; ROSSI-WONGTSCHOWSKI, 1998; FIGUEIREDO; MENEZES, 2000; MENDONÇA; ARAÚJO, 2002; ROCHA et al., 2010). The literature 


\section{SUMMER - Bothus ocellatus}
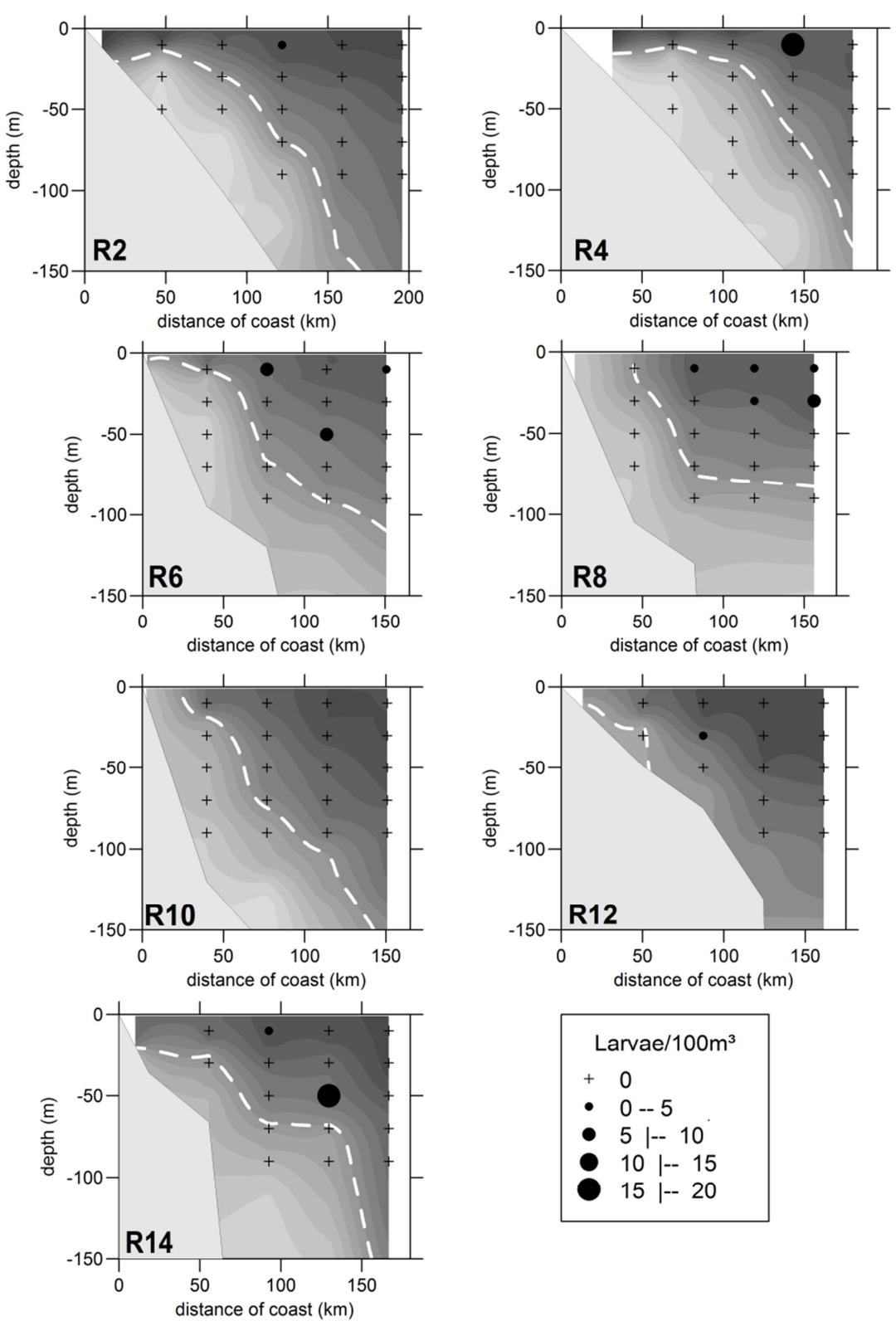

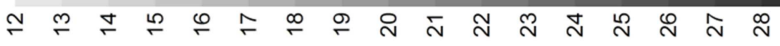
Temperature $\left({ }^{\circ} \mathrm{C}\right)$

Fig. 8. Vertical profiles of temperature $\left({ }^{\circ} \mathrm{C}\right)$ and vertical distribution of Bothus ocellatus larvae during the summer 2002. The density is expressed in larvae $/ 100 \mathrm{~m}^{3}$. The dotted white line represents the characteristic temperature $\left(20^{\circ} \mathrm{C}\right)$ of SACW (South Atlantic Central Water mass). 
reports that $E$. crossotus spawn near the coast in the estuarine region (REICHERT, 1998) and complete their whole life cycle in this area (OLIVEIRA; FAVARO, 2010). In this present study near Cape Frio, juveniles of two species of Etropus were collected. Saad and Fagundes-Netto (1992) observed for E. longimanus females of the same region evidence of spawning at depths of less than $60 \mathrm{~m}$, although they did not detect a specific location for the reproduction of this species. Although the Etropus larvae found do not have characteristics that allow their identification to species level, it is likely that the larvae present in the oceanic zone, specially where the shelf is wider, are E. longimanus that were transported there and then taken to a more coastal zone through oceanographic processes. The dynamics and physical features of this region have been studied by many authors (SILVEIRA et al., 2000; CAMPOS et al., 1995) and it is known that in the oceanic zone of this region the formation of rings and eddies influences the circulation in the shelf area. The circulation of surface water in the area of the present study certainly determines the pattern of the transport and distribution of fish larvae.

Two species of the genus Syacium ( $S$. papillosum and $S$. micrurum) are known on the western coast of the Atlantic ocean including the south-southeastern coast of Brazil, the former occurring from North Carolina to southern Rio Grande do $\mathrm{Sul}\left(35^{\circ} \mathrm{S}\right)$ and the latter from Florida to Guarujá $\left(24^{\circ} \mathrm{S}\right)$ (FIGUEIREDO; MENEZES, 2000). Souza and Chaves (2007) have recorded the occurrence of $S$. micrurum off Santa Catarina State $\left(27.30^{\circ} \mathrm{S}\right)$. Being coastal species, they are captured, respectively, down to about $40 \mathrm{~m}$ and $90 \mathrm{~m}$ depths. However, in studies of the southeastern coast, the occurrence of juveniles and adults of $S$. micrurum has either not been reported (PAIVA-FILHO et al., 1987; ROCHA; ROSSIWONGTSCHOWSKI, 1998; MENDONÇA; ARAÚJO, 2002, ZANI-TEIXEIRA, pers. comm ${ }^{1}$.) or is low (SOUZA; CHAVES, 2007, ROCHA et al., 2010). This species is more abundant on the northeastern coast (OLIVEIRA, 1972; ROCHA et al., 1998). In the Gulf of Mexico, according to Futch and Hoff Jr. (1971), it is probable that the spawning period of $S$. papillosum extends from early spring through to mid-autumn, with most intense activity in summer. The same result was obtained in studies conducted on adults at Cape Frio (SAAD; FAGUNDES-NETTO; 1992) and on the northern coast of Santa Catarina (SOUZA; CHAVES; 2007). The Syacium spp. larvae were more abundant and frequent in summer, which is in accord with these results. Despite these species having coastal habits, their larvae occur particularly as

\footnotetext{
1 ZANI-TEIXEIRA, M. L. (pers. comm.) (zanit@usp.br) Study conducted from February 1981 to January1983 at Trapandé Bay Cananéia, SP, Brazil $\left(25^{\circ} \mathrm{S} ; 48^{\circ} \mathrm{W}\right)$ (unpublished data).
}

from the intermediate zone. Further, according to Futch and Hoff Jr. (1971), the spawning of $S$. papillosum in the Gulf of Mexico does not take place near the coast but at depths greater than $20 \mathrm{~m}$. Something similar seems to happen in the study area where only one larva was found near the coast $(20 \mathrm{~m})$.

Two species of Bothus, B. ocellatus and $B$. robinsi, occur in the southeastern region (FIGUEIREDO; MENEZES, 2000). The study area is located near the southern limit of the area of the occurrence of the former species, which extends from New York to the south of the State of São Paulo $\left(25^{\circ} 30^{\prime} \mathrm{S}\right)$, down to $100 \mathrm{~m}$ depth (FIGUEIREDO; MENEZES, 2000) and it is reef-associated (MACEDO; MONTEIRO-RIBAS, 2006). Only $B$. ocellatus larvae occurred in this present study, these larvae occur predominantly in the summer and in the oceanic zone, the same pattern as that described by Flores-Coto et al. (1991). According to these latter authors, B. ocellatus is among the most abundant flatfishes larvae in the Gulf of Mexico. SanvicenteAñorve et al. (1998), in that same region, in a study undertaken down to the $180 \mathrm{~m}$ isobath, found it to be more abundant in the neritic zone. On the southeastern/southern coast $B$. ocellatus belongs to the neritic and oceanic assemblages (KATSURAGAWA et al.; 2006), though it also occurs in the coastal assemblage.

In a study undertaken by Katsuragawa (pers. comm $^{2}$.), B. ocellatus larvae were more abundant in mid-autumn than at the end of the spring. When these results and those obtained in this present study are analyzed it may be concluded that this species reproduces throughout the year because its larvae occur in all the seasons, though with more intense reproductive activity in summer-autumn, with a peak in the autumn.

In this present study, flatfish larvae were more abundant in the first $40 \mathrm{~m}$ of the water column. A similar pattern has been observed and described for the Pleuronectiformes by many authors such as Weinstein et al. (1980), Tanaka et al. (1989) and Burke et al. (1995). Larvae of B. ocellatus were captured in the neustonic layer at the mouth of Guanabara Bay by Bonecker (1997). The occurrence of larvae closer to the surface may be a reflection of the availability of food, which is greater in this stratum (COMYNS; LYCZKOWSKI-SHULTZ, 2004; SABATÉS, 2004).

Although the habitat of the adults of Syacium spp. and B. ocellatus does not exceed $100 \mathrm{~m}$ depth, their larvae are more frequent beyond this

\footnotetext{
2 KATSURAGAWA, M. (pers. comm.) (mkatsura@usp.br) Study of patterns in larval fish assemblages under the Brazil Current influence, conducted in spring 1997 and autumn 2001 (unpublished data).
} 
isobath, even surpassing the isobath of 1,000 m. The same happens with Etropus spp. but their adult habitat reaches a depth of $190 \mathrm{~m}$. In the summer the larvae of these three species occurred outside the area of influence of the SACW. Aceves-Medina et al. (2003) suggest that Syacium ovale in the Gulf of California spawn in shallow water, eggs and larvae are transported to deeper waters, probably as a strategy to avoid the high predation in the coastal zone, and juveniles return later to the shallow water areas. Syacium spp. and B. ocellatus spawn when the intrusion of SACW is more intense. It is probable that the intrusion of this water mass carries the larvae away from the coastal zone where spawning occurs. The processes that bring back the larvae to the coast need to be more fully understood.

\section{REFERENCES}

ABREU, P. C.; ROBALDO, R. B.; SAMPAIO, L. A.; BIANCHINI, A.; ODEBRECHT, C. Recurrent Amyloodiniosis on broodstock of the Brazilian flounder Paralichthys orbignyanus: dinospore monitoring and prophylactic measures. J. World Aquacult. Soc., v. 36 , n. 1, p. 42-50, 2005.

ACEVES-MEDINA, G.; GONZÁLEZ, E. A.; SALDIERNA, R. J. Larval development of Symphurus williamsi (Cynoglossidae: Pleuronectiformes) from the Gulf of California. Fish. Bull., v. 97, n. 4, p. 738-745, 1999.

ACEVES-MEDINA, G.; SALDIERNA-MARTÍNEZ, R. J.; GONZÁLEZ, E. A. Distribution and abundance of Syacium ovale larvae (Pleuronectiformes: Paralichthyidae) in the Gulf of California. Rev. Biol. Trop., v.51, n. 2, p. 561-570, 2003.

ALMEIDA, Z. S.; VASCONCELOS FILHO, A. L. Contribuição a conhecimento de peixes Pleuronectiformes da área de Itamaracá - PE (Brasil). Trab. Oceanogr., Univ. Fed. Pernambuco, v. 25, p. 69-82, 1997.

ARAÚJO-LIMA, C. A. R. M.; OLIVEIRA, E. C. Transport of larval fish in the Amazon. J. Fish Biol., v. 53, suppl. A, p. 297-306, 1998.

AZEVEDO, M. F. C.; OLIVEIRA, C.; MARTINS, C.; WASKO, A. P.; FORESTI, F. Isolation and characterization of a satellite DNA family in Achirus lineatus (Teleostei: Pleuronectiformes: Achiridae). Genetica, v. 125, n. 2/3, p. 205-210. 2005.

AZEVEDO, M. F. C.; OLIVEIRA, C.; PARDO, B. G.; MARTINEZ, P.; FORESTI, F. Cytogenetic characterization of six species of flatfishes with comments to karyotype differentiation patterns in Pleuronectiformes (Teleostei). J. Fish Biol., v. 70, suppl. A, p. 1-15, 2007.

BURKE, J. S.; TANAKA, M.; SEIKAI, T. Influence of light and salinity on behaviour of larval Japanese flounder (Paralichthys olivaceus) and implications for inshore migration. Neth. J. Sea Res., v. 34, n. 1/3, p. 59-69, 1995.

CAMPOS, E. J. D.; GONÇALVES, J. E.; IKEDA, Y. Water mass and characteristics geostrophic circulation in the South Brazil bight: summer of 1991. J. Geophys. Res., C: Oceans Atmos., v. 100, n. C9, p. 18537-18550, 1995.
CARDENAS, M. Q.; LANFREDI, R. M. Further description of Procamallanus (Spirocamallanus) halitrophus Comb. N. (Nematoda: Camallanidae) from flounder off the Brazilian coast by light and scanning electron microscopy. J. Parasitol., v. 91, n. 3, p. 606-613, 2005.

CASTRO, M. S. C.; BONECKER, A. C. T.; VALENTIN, J. L. Seasonal Variation in Fish Larvae at the Entrance of Guanabara Bay, Brazil. Braz. Arch. Biol. Technol., v.48, n. 1, p. 121-128, 2005.

CASTRO, B. M.; MIRANDA, L. B. Physical oceanography of the western Atlantic continental shelf located between $4^{\circ} \mathrm{N}$ and $34^{\circ} \mathrm{S}$ coastal segment $\left(4^{\circ} \mathrm{W}\right)$. In: BRINK, K. H.; ROBINSON, A. R. (Eds.). The sea. New York: John Wiley, 1998. p. 209-251.

CHAVES, P. T. C.; SERENATO, A. Diversidade de dietas na assembléia de linguados (Teleostei, Pleuronectiformes) do manguezal da Baia de Guaratuba, Paraná, Brasil. Rev. Bras. Oceanogr., v. 46, n. 1, p. 6168, 1998.

CHAVES, P. T. C.; VENDEL, A. L. Indicadores reprodutivos das espécies de Citharichthys Bleeker (Teleostei, Pleuronectiformes) na Baia de Guaratuba, Paraná, Brasil. Rev. Bras. Zool., v. 14, n. 1, p. 73-79, 1997.

CHEN, Y. J.; ZHANG, Q. Q.; QI, J.; SUN, Y. Y.; ZHONG, Q. W.; WANG, X. B.; WANG, Z. G.; LI, S.; LI, C. M. Screening of eye-position related genes with DD-RTPCR and RDA in the hybrids between Japanese flounder (Paralichthys olivaceus) and stone flounder (Kareius bicoloratus). Chin. J. Oceanol. Limnol., v. 27, n. 1, p. 92-99, 2009.

COMYNS, B. H.; LYCZKOWSKI-SHULTZ, J. Diel vertical distribution of Atlantic croaker, Micropogonias undulatus, larvae in the northcentral Gulf of Mexico with comparisons with red drum Sciaenops ocellatus. Bull. Mar. Sci., v.74, n. 1, p. 69-80, 2004.

DIAS, J. F.; FIADI, C. B.; SILBIGER, H. L. N.; SOARES, L. S. H. Reproductive and population dynamics of the Bay whiff Citharichthys spilopterus Günther, 1862 (Pleuronectiformes: Paralichthyidae) in the Mamanguá Inlet, Rio de Janeiro, Brazil. Neotrop. Ichthyol., v. 3, n. 3, p. 411-419, 2005.

EMÍLSSON, I. The shelf and coastal waters off Southern Brazil. Bol. Inst. Oceanogr., v. 11, n. 2, p. 101-112, 1961.

FIGUEIREDO, J. L.; MENEZES, N. A. Manual de peixes marinhos do Sudeste do Brasil. V Teleostei (6). São Paulo: Museu de Zoologia, Universidade de São Paulo, 2000. $116 \mathrm{p}$.

FLORES-COTO, C.; ABUNDIO-LÓPEZ, F.; ZAVALAGARCÍA, F. Larval distribution and abundance of pleuronectiformes from the Southern Gulf of Mexico. Estuarine, Coastal Shelf Sci., v. 32, n. 5, p. 439-450, 1991.

FUTCH, C. R.; HOFF Jr., F. H. Larval development of Syacium papillosum (Bothidae) with notes on adult morphology. St. Petersburg: Marine Research laboratory, 1971. 22 p. (Leaflet Series; v. 4, immature vertebrates, part 1, n. 20).

GIANNINI, R.; PAIVA FILHO, A. M. Análise comparativa da ictiofauna da zona de arrebentação de praias arenosas do Estado de São Paulo, Brasil. Bol. Inst. Oceanogr., v. 43 , n. 2, p. 141-152, 1995. 
GUEDES, A. P. P.; ARAÚJO, F. G.; AZEVEDO, M. C. C. Estratégia trófica dos linguados Citharichthys spilopterus (Günther) e Symphurus tessellatus (Quoy; Gaimard) (Actinopterygii, Pleuronectiformes) na Baia de Sepetiba, Rio de Janeiro, Brasil. Rev. Bras. Zool., v. 21, n. 4, p. 857-864, 2004.

HUANG, W.; CAO, L.; YE, Z. J.; YIN, X. B.; DOU, S. Z. Antioxidative responses and bioaccumulation in Japanese flounder larvae and juveniles under chronic mercury exposure. Comp. Biochem. Physiol., Part C: Toxicol. Pharmacol., v. 152, n. 1, p. 99-106, 2010.

ISHIBASHI, Y.; KOTAKI, T.; YAMADA, Y.; OHTA, H. Ontogenic changes in tolerance to hypoxia and energy metabolism of larval and juvenile Japanese flounder Paralichthys olivaceus. J. Exp. Mar. Biol. Ecol., v. 352, n. 1, p. 42-49, 2007.

KATSURAGAWA, M.; DIAS, J. F. Distribuição do ictioplâncton na região de São Sebastião, SP. Relat. Tec. Inst. Oceanogr., v. 41, p.15-28, 1997.

KATSURAGAWA, M.; MUELBERT, J. H.; DIAS, J. F. O ictioplâncton na região entre o cabo de São Tomé (RJ) e o Chuí (RS). In: ROSSI-WONGTSCHOWSKI, C. L. D. B.; MADUREIRA, L. S. P. (Orgs.). O ambiente oceanográfico de plataforma continental e do talude na região Sudeste-Sul do Brasil. São Paulo: EDUSP: IMESP, 2006. v. 1, p. 359-446.

KURTZ, F. W.; MATSUURA, Y. Early development of four tonguefishes of the genus Symphurus (Osteichthyes: Cynoglossidae) from the southern Brazil. Jpn. J. Ichthyol., v. 41, n. 2, p. 141-148, 1994.

LANES, C. F. C.; OKAMOTO, M.; CAVALCANTI, P. V.; COLLARES, T.; CAMPOS, V. F.; DESCHAMPS, J. C. ROBALDO, R. B.; MARINS, L. F.; SAMPAIO, L. A. Cryopreservation of Brazilian flounder (Paralichthys orbignyanus) sperm. Aquaculture, v. 275, n. 1/4, p. 361-365, 2008.

LEMA, T.; OLIVEIRA, M. F. T. A família Cynoglossidae no extremo-sul do Brasil e Rio da Prata (Pleuronectiformes, Soleoidei). Iheringia, Ser. Zool., v. 50, p. 3-19, 1977.

LEMA, T.; OLIVEIRA, M. F. T.; LUCENA, C. A. S Levantamento preliminar dos Pleuronectiformes do extremo sul do Brasil ao Rio de La Plata (Actinopterygii: Teleostei). Iheringia, Ser. Zool., v. 56, p. 25-52, 1980.

LUNARDON-BRANCO, M. J.; BRANCO, J. O. Alimentação natural de Etropus crossotus Jordan \& Gilbert (Teleostei, Pleuronectiformes, Paralichthyidae), na Armação do Itapocoroy, Penha, Santa Catarina, Brasil. Rev. Bras. Zool., v. 20, n. 4, p. 631-635, 2003.

MACEDO, A. P. S.; MONTEIRO-RIBAS, W. M Pleuronectiformes. In: BONECKER, A. C. T.; CASTRO, M. S. (Eds.). Atlas de larvas de peixes da região central da zona econômica exclusiva brasileira. Rio de Janeiro: Museu Nacional, 2006. p. 176-190. (Série Livros/Documentos REVIZEE SCORE Central; 19).

MARQUES, J. F.; TEIXEIRA, C. M.; PINHEIRO, A.; PESCHKE, K.; CABRAL, H. N. Análisis multivariado de la ecología alimenticia del lenguado anillado, Syacium micrurum (Pisces, Pleuronectiformes), en cabo Verde, Atlantico oriental. Cienc. Mar., v. 35, n. 1, p. 15-27, 2009.
MENDONÇA, P.; ARAÚJO, F. G. Composição das populações de linguados (Osteichthyes, Pleuronectiformes) da Baia de Sepetiba, Rio de Janeiro, Brasil. Rev. Bras. Zool., v. 19, n. 2, p. 339-347, 2002.

MENEZES, N. A.; BENVEGNU, G. Q. On the species of the genus Symphurus from the Brazilian coast, with descriptions of two new species (Osteichthyes, Pleuronectiformes, Cynoglossidae). Pap. Avulsos Dep. Zool., Secr. Agric., Ind. Comer. São Paulo, v. 30, n. 11, p. 137-170, 1976.

MIRANDA, L. B. Forma de correlação T-S de massas de água das regiõos costeiras e oceânicas entre o cabo de São Tomé (RJ) e a Ilha de São Sebastião (SP), Brasil. Bol. Inst. Oceanogr., v. 33, n. 2, p. 105-119, 1985.

MUNROE, T. A.; ROSS, S. W. Distribution and life history of two diminutive flatfishes, Citharichthys gymnorhinus and C. cornutus (Pleuronectiformes: Paralichthyidae), in the western North Atlantic. Fish. Bull., v. 108, n. 3, p. 323-345, 2010.

OHNO, Y.; KAWANO, F.; HIRAZAWA, N. Susceptibility by amberjack (Seriola dumerili), yellowtail ( $S$. quinqueradiata) and Japanese flounder (Paralichthys olivaceus) to Neobenedenia girellae (Monogenea) infection and their acquired protection. Aquaculture, v. 274, n. 1, p. 30-35, 2008.

OLIVEIRA, E. C.; FÁVARO, L. F. Reproduction of the flatfish Achirus lineatus (Pleuronectiformes: Achiridae) in Paranagua Bay, state of Parana, a subtropical region of Brazil. Zoologia, v. 27, n. 4, p. 523-532, 2010.

OLIVEIRA, A. M. E. Peixes estuarinos do nordeste oriental brasileiro. Arq. Cienc. Mar, v. 12, n. 1, p. 35-41, 1972.

PAIVA, M. P.; MONTE, H. A. B.; MOREIRA, L. H. A. Distribuição e abundância de linguados no estado do Rio de Janeiro (Brasil) - (Osteichthyes: Pleuronectiformes). Bol. Tecn. Cient. CEPENE, v. 9, n. 1, p. 191-204, 2001.

PAIVA-FILHO, A. M.; GIANNINI, R., RIBEIRO-NETO, F. B.; SCHMIEGELOW, J. M. M. Ictiofauna do complexo baia-estuário de Santos e São Vicente, SP, Brasil. Rel. Interno Inst. Oceanogr., Univ. São Paulo, n. 17, p. 110. 1987.

PAIVA-FILHO, A. M.; SCHMIEGELOW, J. M. M.; GIANNINI, R., RIBEIRO-NETO, F. B. Contribuição ao conhecimento da ictiofauna da região da ilha de Alcatrazes (SP), Brasil. Rel. Interno Inst. Oceanogr., Univ. São Paulo, n.25, p.1-6, 1989.

POTTHOFF, T. Clearing and staining techniques, p. 35-37, In: MOSER, H. G.; RICHARDS, W. J.; COHEN, D. M.; FAHAY, M. P.; KENDALL Jr., A. W.; RICHARDSON, S. L. (Eds). Ontogeny and systematics of fishes: based on an international symposium dedicated to the memory of Elbert Halvor Ahlstrom. Lawrence: American Society of Ichthyologists and Herpetologists, 1984. 759 p. (Special Publication, n.1)

REICHERT, M. J. M. Etropus crossotus, an annual flatfish species; age and growth of the fringed flounder in South Carolina. J. Sea Res., v. 40, n. 3/4, p. 323-332. 1998.

ROBALDO, R.; PEREIRA Jr., J.; SAMPAIO, L. A.; KUTTER, V.; BIANCHINI, A. Ovoposição e desenvolvimento inicial de Caligus sp. (Copepoda: Caligidae) parasita de juvenis do linguado Paralichthys orbignyanus (Teleostei: Paralichthyidae) em cativeiro. Atlântica, v. 24, n. 2, p. 85-88, 2002. 
ROCHA, G. R. A.; ROSSI-WONGTSCHOWSKI, C. L D. B. Demersal fish community on the inner shelf of Ubatuba, southeastern Brazil. Rev. Bras. Oceanogr., v. 46, n. 2, p. 93-109, 1998

ROCHA, M. L. C. F.; FERNANDEZ, W. S.; PAIVA FILHO, A. M. Spatial and temporal distribution of fish in Palmas Bay, Ubatuba, Brazil. Braz. J. Oceanogr., v. 58, n. 1, p. 31-43, 2010.

ROCHA, L. A.; ROSA, I. L.; ROSA, R. S. Peixes recifais da costa da Paraíba, Brasil. Rev. Bras. Zool., v. 15, n. 2, p. 553-566, 1998.

SAAD, A. M.; FAGUNDES-NETTO, E. Aspectos da biologia reprodutiva de fêmeas de Etropus longimanus Norman, 1933 (Bothidae) da região de Cabo Frio, Rio de Janeiro. 1. Tamanho da primeira maturação, tipo e época de desova. Bol. Inst. Oceanogr., v. 40, n. 1/2, p. 1-13, 1992.

SABATÉS, A. Diel vertical distribution of fish larvae during the winter-mixing period in the Northwestern Mediterranean. ICES J. Mar. Sci., v.61, n. 8, p. 1243 1252, 2004.

SAKAKURA, Y. Larval fish behavior can be a predictable indicator for the quality of Japanese flounder seedlings for release. Aquaculture, v.257, n. 1/4, p. 316-320, 2006.

SALDIERNA-MARTINEZ, R. J.; ACEVES-MEDINA, G; GONZALEZ-NAVARRO, E. A. Larval development of the spotfin tonquefish (Symphurus oligomerus Mahadeva and Munroe, 1990) (Pleuronectiformes: Cynoglossidae) from the Gulf of California, Mexico. Fish. Bull., v. 108, n. 1, p. $45-55,2010$.

SAMPAIO, L. A.; FREITAS, L. S.; OKAMOTO, M. H.; LOUZADA, L. R.; RODRIGUES, R. V.; ROBALDO, R. B. Effects of salinity on Brazilian flounder Paralichthys orbignyanus from fertilization to juvenile settlement. Aquaculture, v. 262, n. 2/4, p. 340-346, 2007

SANVICENTE-AÑORVE， L.; FLORES-COTO, C.; SÁNCHEZ-VELASCO, L. Spatial and seasonal patterns of larval fish assemblages in Southern Gulf of Mexico. Bull. Mar. Sci., v. 62, n. 1, p. 17-30, 1998.

SHIMADA, Y.; SEIKAI, T. Delayed growth of albino in Japanese flounder larvae and juveniles. Fish. Sci., v. 74, n. 2, p. 455-457, 2008a.

SHIMADA, Y.; SEIKAI, T. Surviving ability in albino newly hatched larvae of Japanese flounder determined by high salinity tolerance. Fish. Sci., v. 74, n. 3, p. 687-689, 2008b.

SHIROZU, T.; SHIRAISHI, E.; YOSHINAGA, N. YAMAGUCHI, T.; KITANO, T. The mechanism of transcriptional regulation of Mullerian inhibiting substance in Japanese flounder (Paralichthys olivaceus). Cybium, v. 32, n. 2, suppl., p. 90-91, 2008

SILVEIRA, I. C. A.; SCHMIDT, A. C. K.; CAMPOS, E. J. D.; GODOI, S. S.; IKEDA, Y. A corrente do Brasil ao largo da costa leste brasileira. Rev. Bras. Oceanogr., v. 48, n. 2, p. 171-183, 2000. [Review].

SMITH, P. E.; RICHARDSON, S.L. Standard techniques for pelagic fish egg and larva surveys. Rome: FAO, 1977. 100 p. (FAO Fisheries Technical Papers; v. 175).

SOUZA, L. M.; CHAVES, P. T. Atividade reprodutiva de peixes (Teleostei) e o defeso da pesca de arrasto no litoral norte de Santa Catarina, Brasil. Rev. Bras. Zool. v. 24, n. 4, p. 1113-1121, 2007.
SUN, P.; YOU, F.; LIU, M.; WU, Z.; WEN, A.; LI, J.; XU, Y.; ZHANG, P. Steroid sex hormone dynamics during estradiol-17 $\beta$ induced gonadal differentiation in Paralichthys olivaceus (Teleostei). Chin. J. Oceanol. Limnol., v. 28, n. 2, p. 254-259, 2010.

SVERDRUP, H. U.; JOHNSON, M. W.; FLEMING, R. H. The oceans, their physics, chemistry, and general biology. New York: Prentice Hall, 1942. 1087 p.

TANAKA, M.; GOTO, T.; TOMIYAMA, M. SUDO, H.; AZUMA, M. Lunas-phased immigration and settlement of metamorphosing Japanese flounder larvae into the nearshore nursery ground. Raap. P.-V. Reun. - Cons. Int. Explor. Mer, v. 191, p. 303-310, 1989.

TANAKA, Y.; YAMAGUCHI, H.; GWAK, W. S.; TOMINAGA, O.; TSUSAKI, T.; TANAKA, M. Influence of mass release of hatchery-reared Japanese flounder on the feeding and growth of wild juveniles in a nursery ground in the Japan Sea. J. Exp. Mar. Biol. Ecol., v. 314, n. 2, p. 137-147, 2005.

THATCHER, V. E.; PEREIRA Jr., J. Brasilochondria riograndensis gen. nov., sp. nov. (Copepoda, Chondracanthidae) a parasite of flounders of Rio Grande do Sul State, Brazil. Rev. Bras. Zool., v. 21, n. 3, p. 515518, 2004.

TOMIYAMA, T.; MIZUNO, T.; UENOYAMA, D.; ENOMOTO, M.; SOHTOME, T. Offshore collection of larval Japanese flounder Paralichthys olivaceus: implication for transport-induced mortality. Fish. Sci., v.74, n. 2, p. 449-451, 2008.

VELloso, A. L.; PEREIRA Jr., J.; COUSIN, J. C. B. Therodamas fluviatilis (Copepoda: Ergasilidae), parasito de Paralichthys orbignyanus (Teleostei: Paralichthyidae) do estuário da Lagoa dos Patos e Costa Adjacente, RS, Brasil. Bol. Inst. Pesca, v. 31, n. 1, p. 65-71, 2005.

WAKABARA, Y.; REZENDE, E. K.; TARARAM, A. S. Amphipods as one of the main food components of three Pleuronectiformes from the continental shelf of South Brazil and North Uruguay. Mar. Biol., v. 68, n. 1, p. 6770, 1982.

WEINSTEIN, M. P.; WEISS, S. L.; HODSON, R. G.; GERRY, L. R. Retention of three taxa of postlarval fishes in an intensively flushed tidal estuary, Cape Fear River. North Carolina. Fish. Bull., v. 78, n. 2, p. 419436, 1980.

YAMAGUCHI, T.; KITANO, T. The mechanism of transcriptional regulation of $\mathrm{P} 450$ aromatase gene by Foxl2 in Japanese flounder (Paralichthys olivaceus). Cybium, v. 32, n. 2, suppl., p. 74-76, 2008.

ZAR, J. H. Biostatistical analysis. 4. ed. Upper Saddle River: Prentice Hall, 1999. p. 663.

(Manuscript received 18 October 2012; revised 28 November 2013; accepted 21 January 2014) 